\title{
Energy Yield Value Evaluation of a HHO Technology Induced Diesel Engine
}

\author{
Vignesh Sai ${ }^{1}$, Alok Kumar Nayak ${ }^{2}$ \\ ${ }^{1,2}$ College of Engineering and Technology, Mechanical Engineering, Bhubaneswar, Odisha, India
}

\begin{abstract}
By some estimates, the total number of vehicles worldwide could double to 2.5 billion by 2050.And the number is increasing day by day and the pollutants it releases are carbon dioxide, nitrogen dioxide, sulphur dioxide, sulphur trioxide, hydrocarbons which damage the atmosphere and changes the climate. A rough estimate shows that 14, 560 miles average per year per vehicle and an estimate of 30 average kilometers/liter gives an average of 589 gallons per year and an estimation of 9.320 pounds of carbon dioxide per year. The alarming statistics show that there is a widespread need of using the alternative sources of energy and at the same time utilizing the available resources efficiently. The study shows the aim of decreasing the vehicle emissions by using the brown gas enriched fuel into an IC engine and explaining its advantage over conventional engines. Finding the characteristics of an engine such as efficiency and emission traits and comparing it with conventional and other enriched engines.
\end{abstract}

Keywords: Energy Yield Value, RPM, Torque, Fuel, Energy, Combustion Heat

\section{Introduction}

As the growing needs of hydrocarbon fuel makes it costlier and at the same time there is a major disadvantage of using this fuel is emissions which pollute the environment and increase the need of replacement of the fuel.As the difficulty to find the best alternative solution is another tough task for the scientists, still the use of hydrogen as a fuel is a good idea which has higher reactivity, higher energy content, heating value than diesel, flammability but it has major demerits such as storage which makes its use a difficult one. If we use diesel and air, disadvantages are emission and scarcity, a better alternative is in between the two solutions is the mixture of diesel air and hydrogen enriched fuel which has increased values than the diesel mixture.In this context we will be showing how it varies and to what extent and making the cost analysis of the design to install it in a four wheeler.

\section{How the Mixture of $\mathrm{H} 2$ Diesel and Air be a Fuel?}

Getting into theoretical field the, Oxy-Hydrogen gases will combust in the combustion chamber when brought to its auto-ignition or self-ignition temperature. For a stoichiometric mixture at normal atmospheric pressure, autoignition of oxy hydrogen gas occurs at about $570^{\circ} \mathrm{C}\left(1065^{\circ} \mathrm{F}\right)$.

\section{Brown Gas (HHO) as a Fuel}

The gas HHo is a mixture of monoatomic and diatomic hydrogen and oxygen and a special type of water called electrically water santilli Magnecules. Brown gas is produced by a similar design of electrolyser that splits water into its various substitutes. Brown gas has a plethora has unusual traits that seem to defy the current chemistry. The main attempt is to help solidify the current theory of brown gas. Brown gas is defined as the entire mixture of gases evolving from an electrolyser specially designed to electrolyze water and not to separate the resulting gases." the brown gas produced by the electrolyser is made to pass through the manifold and then by dissociating it into the diesel fuel, we get the required fuel.

\section{Energy Yield Value}

Energy yield value is defined as the additional output of useful energy that results from injection of a gas into an internal combustion engine. The aim in this context is to quantify the output energy (additional) per unit quantity of injected HHO gas is an important step in developing a more systematic approach.

Consideration used in calculating the Energy Yield Value:

1)The load and speed are maintained as same for both the fuels.

2)The total power output is the same so the total energy doesn't make a difference.

\section{Way of Approach}

Fuel consumption with and without the injection of $\mathrm{HHO}$ gas under identical conditions are taken and the considerations as said above the load and speed are maintained same for both the fuels. fuel consumption for the HHO fuel are done by weighing the fuel container, running the engine for a specific amount of time, weighing the fuel container and calculating the difference to obtain the weight of fuel used during the test period. NOTE: weight is a better consideration then volume because the volume is dependent on various other factors such as temperature, pressure and humidity.

For calculating the output power : RPM *torque =horse power

\section{Approach for Energy Yield Value}

NOTE: efficiency is taken as $\mathrm{N}, \mathrm{N} 1=$ engine efficiency without injection, N2=engine efficiency with gas equation, $\mathrm{Ng}=$ additional energy efficiency then

$\mathrm{Ng}=\mathrm{N} 2-\mathrm{N} 1 \mathrm{CONSIDERATION} \mathrm{TOTAL} \mathrm{POWER} \mathrm{OUTPUT}$ IS SAME and energy output per unit of fuel consumed per unit time is given by E-amount of useful energy produced by engine(WATT $\mathrm{x}$ seconds) $\mathrm{m} 1=$ weight of fuel without gas 


\section{International Journal of Science and Research (IJSR) \\ ISSN (Online): 2319-7064}

Index Copernicus Value (2013): 6.14 | Impact Factor (2015): 6.391

injection

$\mathrm{m} 2=$ amount of fuel with gas injection then equation becomes $\mathrm{E} / \mathrm{m} 2-\mathrm{E} / \mathrm{m} 1$

$\mathrm{E} / \mathrm{m} 2-\mathrm{E} / \mathrm{m} 1$

Calculating the efficiency of the engine which defines as output energy divided by the input energy the for the two considerations

$\mathrm{N} 1=\mathrm{E} / \mathrm{km} 1$ where $\mathrm{k}=$ amount of energy per unit of fuel $47 \mathrm{MJ} / \mathrm{Kg}$

fraction of efficiency that results from gas equation $=\mathrm{Ng} / \mathrm{N} 2$ and by substituting the proper equations we get
$1-(\mathrm{N} 2 / \mathrm{N} 1$ or $(\mathrm{N} 2-\mathrm{N} 1) / \mathrm{N} 2$ as the power output is same for both the case we get

$(\mathrm{N} 1 / \mathrm{N} 2)=(\mathrm{E} / \mathrm{km} 1) /(\mathrm{E} / \mathrm{km} 2)$ and finally we conclude that the parameter needed is a function of fuel consumed

$\mathrm{E} / \mathrm{mg}=$ amount of total energy output per gram of gas for finding the yield value ENERGY YIELD $\mathrm{VALUE}=(\mathrm{E} / \mathrm{mg})(1-\mathrm{m} 2 / \mathrm{m} 1)$

Experimental Setup of HHO Cell, Cost Analysis, and Derivation of HHO Induction

Cost Analysis: For a Four Wheeler Automatic or Manual Transmission Truck

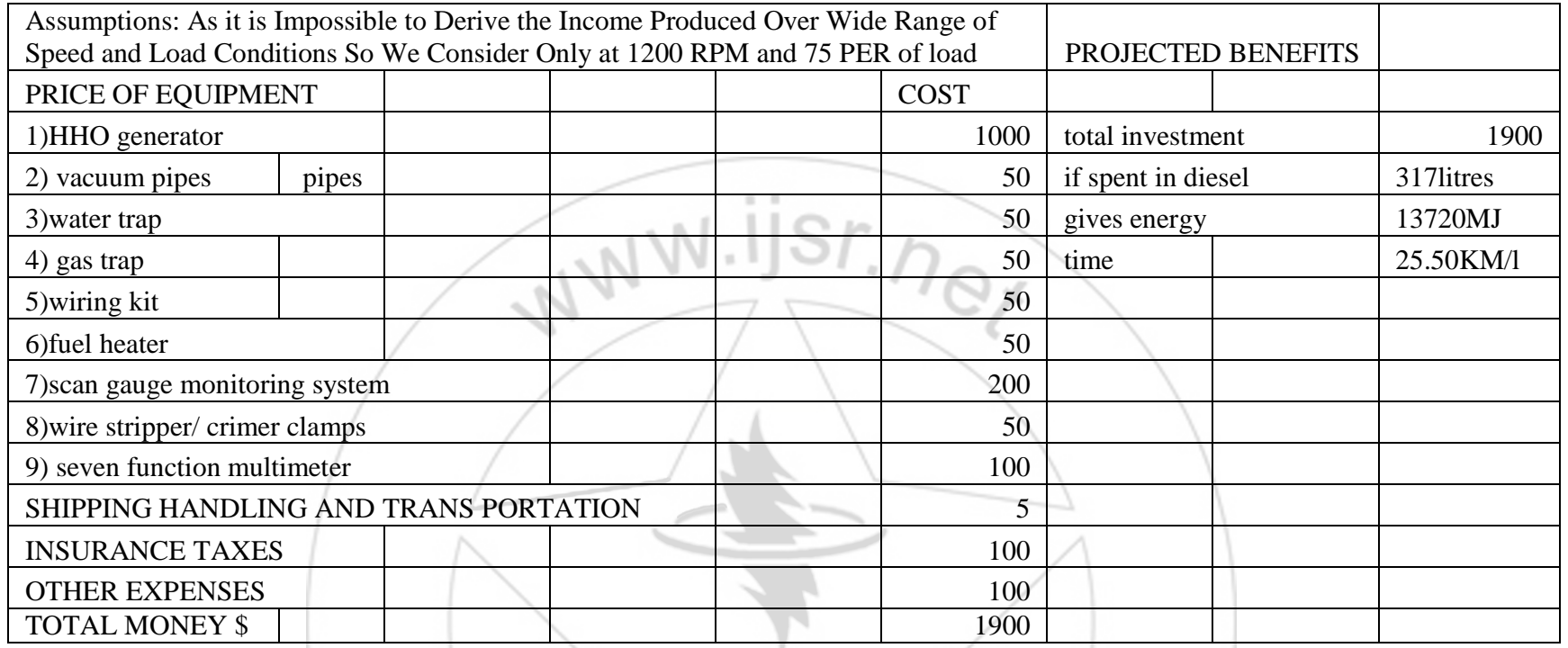

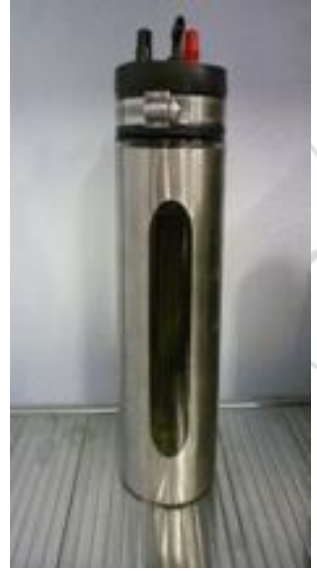

An SS-40 unit are taken into account, The specifications of the HHO cell used in cars and is based upon 12Volts.It has made of stainless steel and the other end is grounded. The gas comes out of the hose barb that is present at the top of the generator. A slide mirror is provided to show the level of electrolyte.

\section{Specifications}

Current $=40$ amperes, Output $=192$ litres per hour Based on the above data and the data known to us we calculate the Hydrogen per amp per hour. Gas constant equation, the value of 192 liters would be equivalent to cubic meters. Total number moles are given by the ideal gas equation:

$\mathrm{PV}=\mathrm{nRT}$ taking the values of ideal gas parameters as standard values

$\mathrm{P}=$ pressure in atmospheres normal atmosphere $\mathrm{R}$ as standard

$\mathrm{V}=$ volume 0.192 cu.meters in this cal

$\mathrm{n}=$ number of gram moles of gas

$\mathrm{T}=$ temperature in kelvin $=298 \mathrm{kA}$ ss40 electrolyser

\section{Calculation}

Solving forn=PV/RTton give the total number of gram moles $=7.85$

The number gram moles of hydrogen gas is $2 / 3$ this amount since HHOis a mixture of two particles so the number moles of hydrogen will be $7.85 \mathrm{x}$ (2/3 standard atomic weight of hydrogen is 1.01 therefore the molecular weight of hydrogen is 2.02grams per mole moles Xmol. Wt gives grams of as which equals 10.55 finally we conclude grams per hour per ampere equals $10.55 / 40=0.26$ 


\section{International Journal of Science and Research (IJSR) \\ ISSN (Online): 2319-7064}

Index Copernicus Value (2013): 6.14 | Impact Factor (2015): 6.391

\begin{tabular}{|c|c|c|c|c|c|c|c|c|c|c|}
\hline $\begin{array}{c}\text { HYDROGEN } \\
\text { ADDITIN }\end{array}$ & $L O A D$ & $R P M$ & $\begin{array}{l}F U E L \\
(K g / h r)\end{array}$ & $\begin{array}{c}\text { TORQU in } \\
(N-m)\end{array}$ & AMPERES & $E 1 M J / h r$ & AMPERES & $E 2 M J / h r$ & $\begin{array}{c}H 2 \\
\text { GRAMS/hr }\end{array}$ & $E Y V$ \\
\hline $\mathrm{NO}$ & 25 & 1200 & 18.5 & 538.25 & 0 & 243.1 & 0 & - & 0 & - \\
\hline $\mathrm{NO}$ & 25 & 1800 & 28.57 & 383.69 & 0 & 259.93 & 0 & - & 0 & - \\
\hline YES & 25 & 1200 & 21.31 & 538.25 & 25 & - & 25 & 243.1 & 6.7 & -3.79 \\
\hline YES & 25 & 1800 & 21.31 & 368.78 & 46 & - & 46 & 249.82 & 12.24 & 4.96 \\
\hline $\mathrm{NO}$ & 50 & 1200 & 31.11 & 940.93 & 0 & 424.96 & 0 & - & 0 & - \\
\hline $\mathrm{NO}$ & 50 & 1800 & 51.25 & 707.73 & 0 & 479.4788 & 0 & - & 0 & - \\
\hline YES & 50 & 1200 & 29.48 & 924.66 & 48 & - & 48 & 417.62 & 12.76 & 2.58 \\
\hline YES & 50 & 1800 & 41.73 & 694.17 & 50 & - & 5 & 470.28 & 13.29 & 6 \\
\hline $\mathrm{NO}$ & 75 & 1200 & 42.95 & 1369.37 & 0 & 618.99 & 0 & - & 0 & - \\
\hline $\mathrm{NO}$ & 75 & 1800 & 66.95 & 1130.75 & 0 & 766.0512 & 0 & - & 0 & - \\
\hline YES & 75 & 1200 & 30.29 & 1351.75 & 49 & - & 49 & 610.55 & 13.03 & 14.89 \\
\hline YES & 75 & 1800 & 60.78 & 1149.73 & 48 & - & 48 & 605.03 & 12.76 & 8 \\
\hline $\mathrm{NO}$ & 100 & 1200 & 48.94 & 1538.85 & 0 & 695.03 & 0 & - & 0 & - \\
\hline $\mathrm{NO}$ & 100 & 1800 & 83.46 & 1582.23 & 0 & 1045.28 & 0 & - & 0 & - \\
\hline YES & 100 & 1200 & 44.45 & 1538.85 & 42 & - & 42 & 695.03 & 695.04 & 5.48 \\
\hline YES & 100 & 1800 & 69.85 & 1542.92 & 45 & - & 45 & 1046.28 & 1045.28 & 10.24 \\
\hline
\end{tabular}

\section{Experimental Analysis of the Above Energy Yield}

The analysis is extracted from a test done on a diesel truck engine, it is a eddy current dynamometer. Due to the unavailability of the dynamometer, we successfully conducted the experiment at a research facility so we tried to obtain data in a limited amount of time. IN the series of steps the engine is operated at different loads such as at 25 , $50,75,100$ and the fuel container was weighed before and after each and every run, the fuel, the rpm, load, torque are observed. With the use of the above derived equation we found the values of ENERGY YIELD VALUE with and without the addition of the gas injection and the concentric of the HHo gas practically. We found the values of the amount of hydrogen produced by the HHo electrolyser.

\section{Calculation}

The value of $\mathrm{Mg}$ obtained by 48 amperes x 0.2638 grams amp per hour $=12.66$ grams per hour. Considering for a load condition which is lean that is at 75 percent and the speed is $1200 \mathrm{rpm}$ the energy output value is $618.99 \mathrm{MJ} / \mathrm{hr}$ which is without the addition of the gas

E1=energy released without gas injection $=618.99 \mathrm{MJ} / \mathrm{hr}$,

$\mathrm{Mg}=$ grams of hydrogen released per hour.

so calculating the total energy output per gram of hydrogen gives

$\mathrm{E} 1 / \mathrm{Mg}=48.89 \mathrm{MJ} / \mathrm{g}$ for considering the $1200 \mathrm{rpm}$ and 75 per of load we get the energy $\mathrm{E}$

$\mathrm{E} 2=$ energy released with gas

injection=RPMxTORQUEX747.5X3600/10^6

$=610.55 \mathrm{MJ} / \mathrm{hr}$

the value of output per gram of hydrogen is :E2/Mg

$=48.2 \mathrm{MJ} / \mathrm{g}$

all the values are ready for calculating ENERGY YIELD

VALUE the value of $\mathrm{m} 2 / \mathrm{m} 1$

$30.29 / 42.95=0.705$

recalling the derivation of the ENERGY YIELD VALUE

(E/Mg) $(1-\mathrm{m} 2 / \mathrm{m} 1)$

now resetting we get $(\mathrm{E} 1 / \mathrm{Mg})-(\mathrm{E} 2 / \mathrm{Mg})(\mathrm{m} 2 / \mathrm{m} 1)$ substituting the values we get $14.89 \mathrm{Mj} / \mathrm{g} \mathrm{H} 2$.

similarly we could find the ENERGY YIELD VALUES for 1200 RPM and at 50 per and 100 per at $1200 \mathrm{RPm}$ and 50

load we get the energy yield in $\mathrm{MJ} / \mathrm{g} \mathrm{H} 2$ values as 2.58 and at $1200 \mathrm{RPm}$ and 100 load we get the energy yield value in $\mathrm{MJ} / \mathrm{g} \mathrm{H} 2$ is 5.48

NOTE on 25 per load with the HHO injection all ENERGY YIELD VALUE were positive.

During the experiment we noted the values of brake horse power, mean power, flame speed, and various other properties such as the carbon dioxide emissions before and after the injection of the HHo gas and for nitrogen emissions and other gases. Following are the graphs 


\section{International Journal of Science and Research (IJSR) \\ ISSN (Online): 2319-7064}

Index Copernicus Value (2013): 6.14 | Impact Factor (2015): 6.391
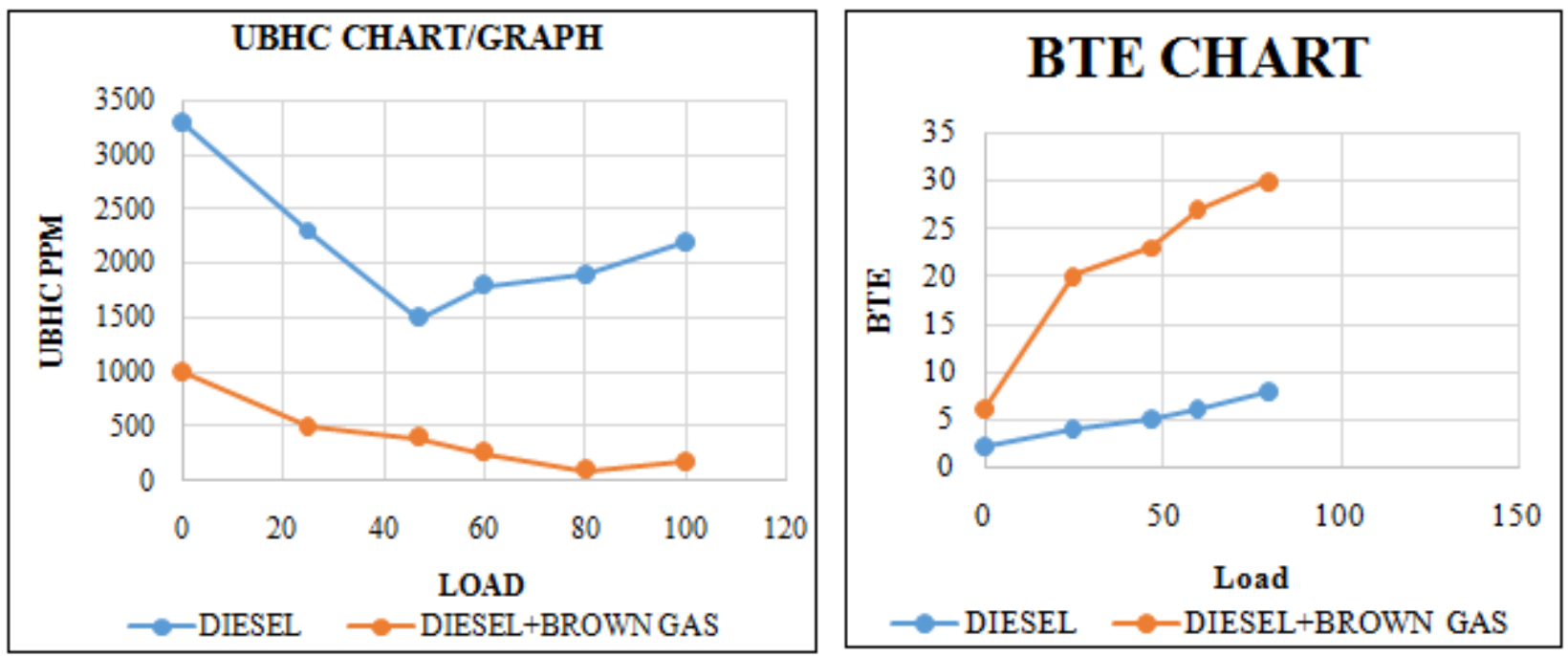

Where, UBHC = unburnt hydrocarbon

$\mathrm{BTE}=$ Brake thermal efficiency.

\section{Drawbacks}

On the first 25 per load with the injection of the HHO gas we found the ENERGY YIELD VALUE to be negative because during the starting of the HHO gas was cold which is often known as cold starting as the engine can produce maximum energy per gram of hydrogen only at/lean conditions. It needs some time for the electrolyser to reach equilibrium with the ambient conditions, and after sometime it works efficiently.

\section{Innovation}

As the main aim was to reduce the emissions introducing the HHO gas was an important step towards climate change and we found that even with the injection of the HHo gas the emissions are reduced by 75 percent but not to a full extent further reduction can be obtained with the help of Fischer trposch Process to convert the carbondioxide into fuel.

\section{Advantages over Conventional Engines and Green Engine (6 Stroke)}

1) It has higher brake power, higher thermal efficiency, and lower fuel consumption and it has lower emissions.

2) In context of the green engine which has robust and heavy structure and higher mean effective pressure when compared with gas injection engine it has moderate values which are even beneficial

3) The gas can be used for various other process such as conversion of carbon dioxide to fuel

4) It don't have higher moving parts as compared to green engine (6 stroke).

5) It is as simple as conventional engine and has same reciprocating parts

\section{Disadvantages of the HHO Engine}

It increase the weight of the vehicle and during the starting of the $\mathrm{HHo}$, the $\mathrm{HHO}$ generator is left for some time to reach equilibrium otherwise the ENERGY YEILD VALUE will be negative.

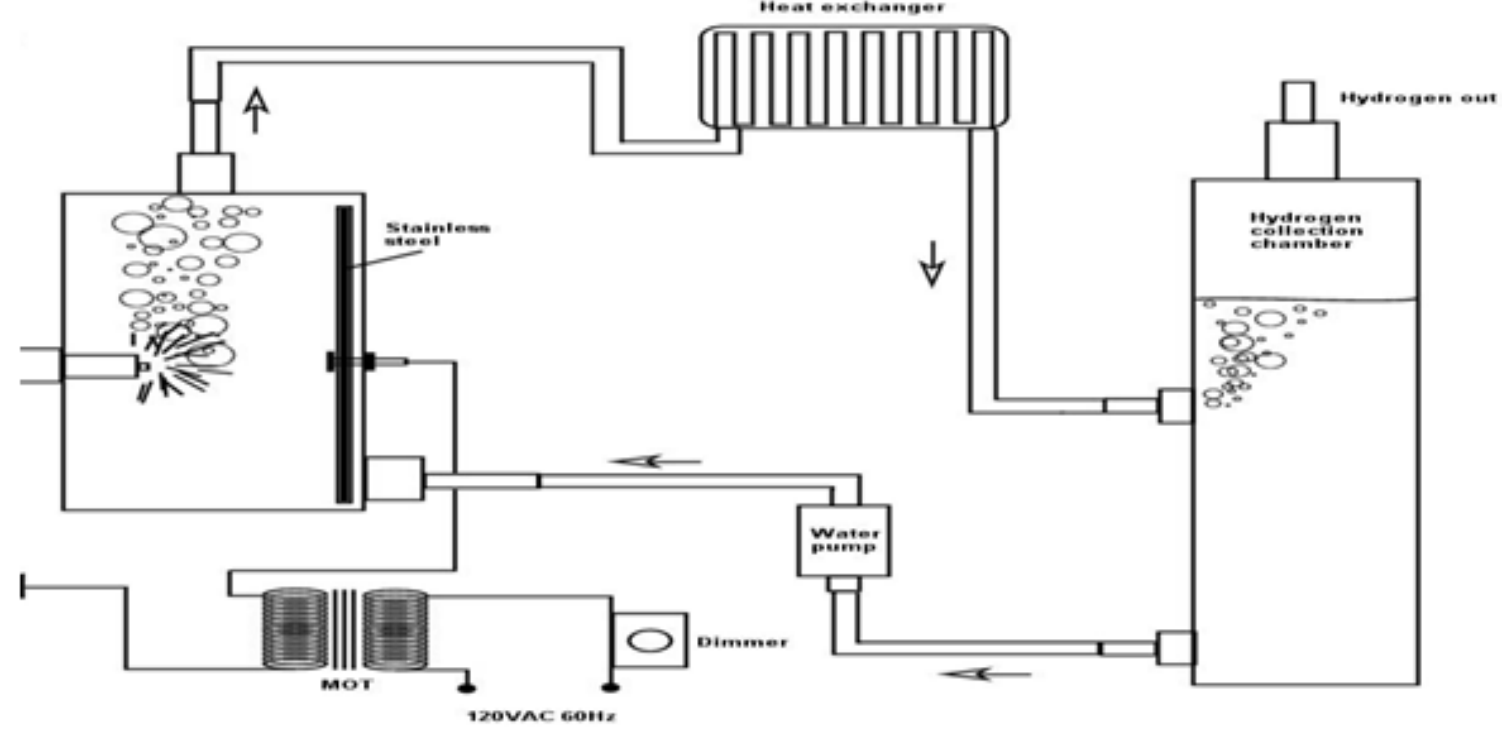

Flow chart of HHo injection (engine)

Volume 5 Issue 5, May 2016 www.ijsr.net 


\section{International Journal of Science and Research (IJSR) \\ ISSN (Online): 2319-7064}

Index Copernicus Value (2013): 6.14 | Impact Factor (2015): 6.391

\section{Conclusion}

Our experiment found that the density of fresh HHO is 51 percent higher than what would be expected but there was no error analysis of the measurement. The exact molecular composition of fresh HHO is uncertain. The average of all the $\mathrm{EYv}$ is $6.5 \mathrm{Mj} / \mathrm{g}$ and the maximum value is $14.89 \mathrm{Mj} / \mathrm{g}$ also the maximum value of $14.89 \mathrm{Mj} / \mathrm{g}$ is over 105 times higher than the heat of combustion of hydrogen gas $0.1419 \mathrm{Mj} / \mathrm{g}$ the $\mathrm{HHO}$ generation which can be used is simple, easily constructed, and easily integrated with existing engine at optimal cost. The optimal size is when the surface area of an electrolyte needed to generate sufficient amount of HHo is twenty times that of the piston surface area also the volume of water needed in the cell is about one and half times the engine capacity.
(ASME).He is serving as a CORE member of ASME CET BHUBANESWAR CHAPTER.

Vignesh Sai is currently pursuing B.Tech degree in Mechanical Engineering From College of Engineering and Technology (BPUT), Bhubaneswar, Odisha, India. He is currently the member of American Society Of Mechanical Engineering (ASME).He is serving as a CORE member of ASME CET BHUBANESWAR CHAPTER.

\section{References}

[1] Balan G A field study of the Effects of the Hydrogen Generating System on Power, Fuel Economy and Emissions in Diesel and Diesel Engine.ASME:1999 Spring Technical Conferences(32_2)(1999) 31-36.

[2] Saed A. musmar "Effect of HHo gas emissions used in a Si engine : Fuel 90(2011) page no 3066-3070.

[3] Eckman C. Plasma Orbital Expansion of the Electrons in Water Proceeding of NPA on the year.

[4] National Aeronautics \& Space Administration (NASA).Washington D.C. Report NASA TN D8487Authorised by john F.cassidy on the"Emissions \& Total energy consumption of a multicyclinder piston engine running on gasoline \& a hydrogen-gasoline mixture." It is an experimentation. which was held by the well-known aeronautics centre in America \& an article \& journal

[5] Al-Rousan, A.A., Reduction of Fuel consumption in gasoline engines by introducing $\mathrm{HHO}$ gas into intake manifold, international journal of hydrogen energy 35 (2010) 1293

[6] HHO gas with Bio-Diesel as a dual fuel with Air Preheating technology". E-book in www.sciencedirect.com, published by R.B.Durairaj and J.Shanker, Faculty of engineering \& technology, SRM University, Chennai.

[7] A book on "Internal Combustion Engine" by Domkundwar Heywood J.B "internal combustion engine fundamentals ', Tata Mcgraw Hill publishing company limited, Newyork 1988.

[8] An experimental investigation of hydrogen enriched air induction in a diesel engine system $\mathrm{N}$ sravanan, $\mathrm{G}$ Nagarjan International joural of hydrogen energy 33(2008)

[9] Jacob Wall effect of Brown's gas enriched hydrocarbon on engine emission and performance National Science foundation (2010).

\section{Author Profile}

Alok Kumar Nayak is currently pursuing B.Tech degree in Mechanical Engineering From College of Engineering and Technology (BPUT), Bhubaneswar, Odisha, India. He is currently the member of American Society Of Mechanical Engineering 